\title{
Basement Depth Estimation Using Euler Deconvolution and Source Parameter Imaging; a Case Study of Northeastern Part of Sokoto Basin, Nigeria
}

\author{
Abubakar I*, Bonde D. S, Raboh Y \\ Kebbi State University of Science and Technology, Aliero, Kebbi State, Nigeria
}

DOI:10.36348/SJEAT.2019.v04i09.008 $\quad$ | Received: 20.09.2019| Accepted: 27.09.2019 | Published: 30.09 .2019

*Corresponding author: Abubakar I

\section{Abstract}

Euler deconvolution and Source Parameter Imaging (SPI) geophysical interpretation techniques using Oasis Montaj version 6.4 was applied to estimate basement depth of northeastern part of Sokoto basin, northwestern Nigeria. The study area lies between longitudes of 505"E to 605"E and latitude $1205 " \mathrm{~N}$ to $1305 " \mathrm{~N}$. The results of the studies indicate an increase in sedimentation northwards, with several depressions on the basement rock. The Euler deconvolution results shows the maximum depth in the study area to be $2.39 \mathrm{~km}$, while Source parameter imaging indicates $1.79 \mathrm{~km}$ to be the highest depth. The areas where higher sedimentary thickness are observed such as sheet 11 (Rabah) and sheet 12 (Isah), are the most prospect sites where threshold temperatures could be attained.

Keywords: Aeromagnetic Data, Euler Deconvolution, Source Parameter Imaging, Oasis Montaj Software and Sedimentary thickness Threshold temperature.

Copyright @ 2019: This is an open-access article distributed under the terms of the Creative Commons Attribution license which permits unrestricted use, distribution, and reproduction in any medium for non-commercial use (NonCommercial, or CC-BY-NC) provided the original author and source are credited.

\section{INTRODUCTION}

Geophysical methods have played and will continue to play an increasingly important role in the economy of the world. This is mainly as a result of radical technical improvements in instrumentations, field methods and modern interpretation techniques resulting from the emergence of large digital computers and their applications. Several geophysical techniques are available for investigating the earth's interior for mineral exploration purpoes. Magnetic method, however, has remained one of the most vital geophysical tools for understanding the subsurface geology. Magnetic survey is employed to investigate subsurface geology on the basis of variations of magnetic anomalies in the Earth's magnetic field resulting from the magnetic properties of the underlying rocks. The most distinguishing feature of this method, compared with other geophysical schemes, is the rapid rate of coverage and low cost per unit area explored [1]. The use of this method makes it possible for geophysicists to acquire data regardless of ownership or accessibility of remote lands of interest. This inherent advantage has made it possible for large scale airborne magnetometer survey to be carried out around the globe. Some of the roles of aeromagnetic survey as outlined by Sharma [2], Hamza and Garba [3] are as follows:
- Determination of depths to basement rocks

- Recognition and interpretation of faulting, shearing and fracturing not only as potential hosts for a variety of minerals but also an indirect guide to epigenetic, stress related mineralization in the surrounding rocks, and

- Direct detection of deposits of certain iron ores.

In this study, a high resolution aeromagnetic data of Northeastern part of Sokoto Basin is investigate using Euler deconvolution and source parameter as interpretation techniques in order to estimate the sedimentary thickness of the area thus infer portions in the study area where threshold temperatures necessary for maturation of hydrocarbons could be attained. The minimum thickness of sediments required to attain threshold temperature is $2.13 \mathrm{~km}$ [4].

Euler deconvolution technique provides automatic estimates of sources, location and depth to basement. Therefore, Euler deconvolution is both boundary finder and depth estimator. The most useful result of Euler deconvolution are the delineation trends and depth. Source Parameter Imaging technique is the quick, easy and powerful method for calculating the depth of magnetic sources, its accuracy has shown to be 
$\pm 20 \%$ in test on real data sets. This accuracy is almost similar to that of Euler deconvolution, however source parameter imaging has the advantage of producing more complete set of coherent solution points and is easier to use.

The aim and objectives of this study is to estimate the basement depths of Northeastern part of Sokoto Basin using Euler Deconvolution and Source Parameter Imaging interpretation techniques to infer prospect of hydrocarbon maturation.

\section{Location and Geology of the Study Area}

The study area is located at the northeastern part of Sokoto Basin, North Western Nigeria, bounded by longitudes of $5^{0} 5^{\prime \prime} \mathrm{E}$ to $6^{0} 5^{\mathrm{N}} \mathrm{E}$ and latitude $12^{0} 5^{\mathrm{N}} \mathrm{N}$ to $13^{0} 5^{\prime} \mathrm{N}$. It includes Rabah, Isah, Gandi and Mafara respectively covered by sheets No. 11, 12, 30 and 31 . The Sokoto Basin which forms the south-eastern part of Iullumenden Basin, is located in the Northwestern Nigeria.
It consists predominantly of great undulating plain with an average elevation varying 250 to $400 \mathrm{~m}$ above sea level. The sediment of Sokoto Basin were accumulated during four main phases of deposition [57]. Overlying the Pre-Cambrian Basement uncomformably, the Illo and Gundumi Formations, made up of grits and clays, constitute the PreMaastrichtian continental intercalaire of West Africa $[8,5]$. They are overlain uncomformably by the Maastrichtian Rima Group, consisting of mudstones and friable sandstones (Taloka and Wurno Formations) separated by the fossiliferous Dukamaje Formation [8, 5]. The Dange and Gamba Formation (mainly shales) separated by the calcareous Kalambaina constitute the Paleocene Sokoto Group. The overlying Gwandu Formation forms the Post Palecene Continental Terminal. These sediments dip gently and thicken gradually towards the northwest with a maximum thickness of over $1200 \mathrm{~m}$ near the frontier with Niger Republic [7].

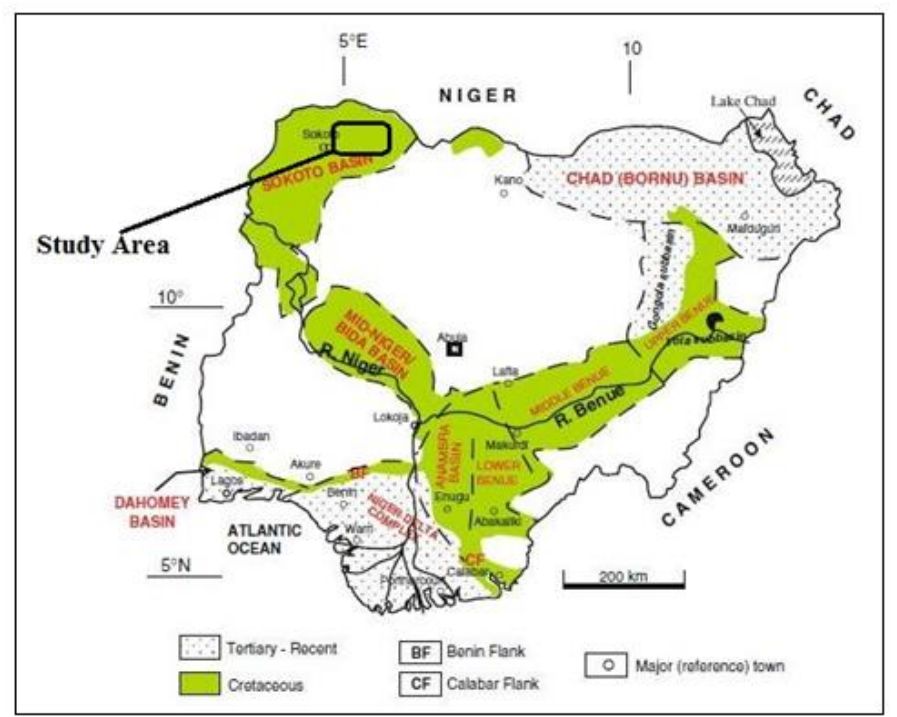

Fig-1: Geological Map of Nigeria Showing the Study Area [9]

\section{LITERATURE REVIEW}

Kamba and Ahmed [10], applied source parameter imaging to determine depth to basement in parts of lower Sokoto basin. The result shows that the sedimentary thickness of the area ranges from $2.8 \mathrm{~km}$ to $3.0 \mathrm{~km}$. Ofoha et al., [11] determined magnetic basement depth over parts of sokoto basin, using improved source parameter imaging (ISPI) technique. The result revealed that the sedimentary thickness of the area ranges from $-3384.4 \mathrm{~m}$ to $54.1 \mathrm{~m}$. Bonde et al., [12] applied spectral depth analysis to determine the sedimentary thickness of Sokoto Basin. The result of their findings show $2.88 \mathrm{~km}$ as the maximum sedimentary thickness of the area. Okonkwo et al., [13] interpreted high resolution aeromagnetic data to determine sedimentary thickness over part of Bida Basin using source parameter imaging, Euler deconvolution and spectral method.
Result from source parameter imaging shows that the depth to magnetic bodies ranges from $107.74 \mathrm{~m}$ to $4972.94 \mathrm{~m}$. while Euler deconvolution revealed maximum sedimentary thickness of $3.56 \mathrm{~km}$. Sawuta et al., [14] uses source parameter imaging and Euler deconvolution to estimate depth to magnetic sources of parts of Benue Trough. Source parameter results revealed a maximum sedimentary thickness of 4908.178 m while Euler deconvolution result revealed a depth of $4050.1 \mathrm{~m}$.

\section{MATERIALS AND METHODS}

High Resolution Aeromagnetic (HRAM) data of Rabah (Sheet 11), Isah (Sheet 12), Gandi (Sheet 30) and Mafara (Sheet 31), which covers the area under consideration, were obtained from the Nigerian Geologic Survey Agency (NGSA). The data which is in 
half degree sheet, was compiled from the data collected at a flight altitude of $80 \mathrm{~m}$, along NE-SW flight lines with approximate spacing of $500 \mathrm{~m}$. The residual anomaly was separated from the regional magnetic field by using the polynomial fitting method for all the values in the grid using Surfer 13 software. The residual anomaly data was interpolated using a minimum curvature gridding algorithm, available in the Geosoft Oasis Montaj (version 6.4.2) Module, with a grid cell size of $250 \mathrm{~m}$. Source parameter imaging and Euler deconvolution techniques were applied on the residual

$$
\left(x-x_{o}\right) \frac{\partial T}{\partial x}+\left(y-y_{o}\right) \frac{\partial T}{\partial y}+\left(z-z_{o}\right) \frac{\partial T}{\partial z}=N(B-T)
$$

Where $\mathrm{T}$ is the total field at $(\mathrm{x}, \mathrm{y}, \mathrm{z})$ and $\mathrm{B}$ is the regional value and $\mathrm{N}$ is the structural index. Assuming various measurement point and known $\mathrm{N}$, the above equation can be solved with least squares procedure for unknowns $\mathrm{x}_{0}, \mathrm{y}_{0}, \mathrm{z}_{0}$ and $\mathrm{B}$. An important parameter in the Euler equation is the structural index $\mathrm{N}$. This is a homogeneity factor relating the magnetic field and its gradient components to the location of the source. A poor choice of the structural index has been shown to cause a diffuse solution of source locations and serious biases in depth estimation. Both Thompson [16] and Reid et al., [17], suggested that a correct $N$

$$
\mathrm{A}_{1}(\mathrm{x}, \mathrm{z})=\frac{\partial m}{\partial y}(\mathrm{x}, \mathrm{z})-\mathrm{j} \frac{\partial m}{\partial x}(\mathrm{x}, \mathrm{z})
$$

Where $\mathrm{m}(\mathrm{x}, \mathrm{z})$ is the magnitude of the anomalous total magnetic field, $\mathrm{j}$ is the imaginary number, while $\mathrm{x}$ and $\mathrm{z}$ are Cartesian coordinates for the vertical and horizontal directions, respectively.

\section{RESULTS \\ ANALYSIS/DISCUSSION/CONCLUSION/RECO MMENDATION}

Total Magnetic Intensity (TMI) Map of the study area (Figure-2) has a magnetic intensity values magnetic field grid to aid interpretation because they are best suited for the research interest of the work.

\section{Euler Deconvolution}

The Euler Deconvolution is a 3-Dimensional semi-automatic interpretation technique widely used in depth estimation and delineation of a wide variety of geologic structures. It is based on Euler homogeneity equation (1) which relates the potential field (magnetic or gravity) and its gradient components to the location of the sources, by the degree of homogeneity $\mathrm{N}$, interpreted as a structural index [15].

gives the tightest clustering of the Euler solutions around the geologic structure of interest. Thompson [16] gives more detailed discussion on the degree of homogeneity of potential fields and structural indices of Euler Deconvolution.

\section{Source Parameter Imaging Method}

This was also employed in this work to estimate the depth from the local wavenumber of the analytical signal. The analytical signal $\mathrm{A}_{1}(\mathrm{x}, \mathrm{z})$ is given as $[18,19]$ :

ranging from $-71.3 \mathrm{nT}$ to $120.7 \mathrm{nT}$ and is marked by both high and low magnetic signatures. These variations may be due to several factors such as; difference in lithology, magnetic susceptibility, variation in degree of strike, depth and difference in lithology. These shows that sedimentary thickness of Northeastern part of sokoto basin increases from south to north part of the study area. This correlete with the works of Kamba \& Ahmed [10] and Bonde et al., [12].
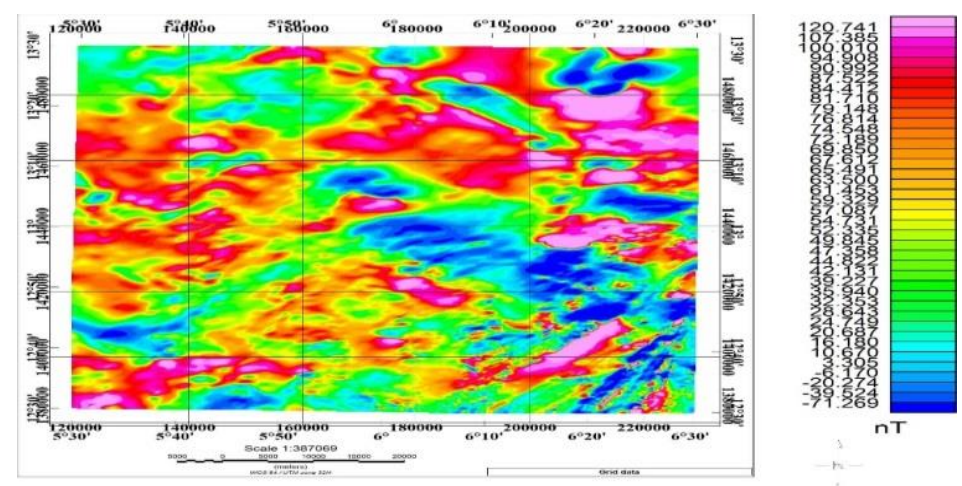

Fig-2: Total Magnetic Intensity (TMI) of the study area

The regional field values from regional map of the study area (Figure-3) which are large features that generally show up as trends and are caused by deeper homogeneity of the earth crust were removed from the total magnetic intensity grid by the method of least squares approach using polynomial regression method.
The left over in the gridded data after removing the regional field is the residual field (Figure-4) caused by high frequency shallow anomalies which corresponds to the location of the target anomalous bodies like structures. The residual map of the study area revealed that the magnetic field intensity ranges from -113.235 
nT to $77.000 \mathrm{nT}$. This indicates that the study area is characterized with low (blue colour) and high (pink colour) magnetic signature.

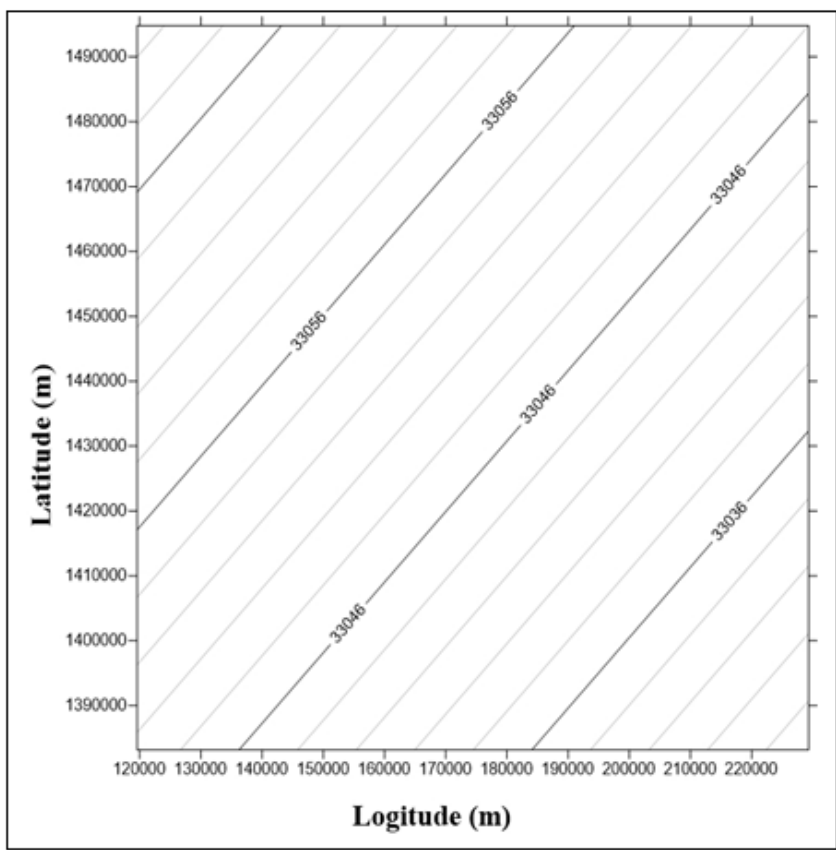

Fig-3: Regional field map of the area
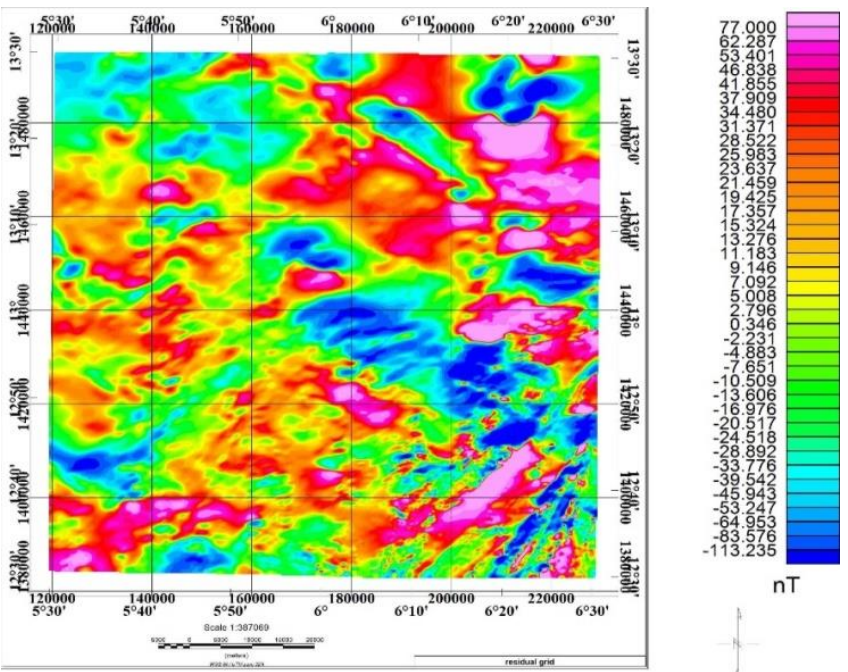

nT

Fig-4: Residual field map of the area

Euler Deconvolution method and Source Parameter Imagine (SPI) were applied on the Residual Magnetic Intensity grid using the Euler 3D extension module and SPI extension module of the Oasis Montaj software. Depth obtained by source parameter imaging
(SPI) ranged from $187.793 \mathrm{~m}$ to $1791.393 \mathrm{~m}$. Results from this study indicate that deep seated bodies are predominant around Rabah and Isah parts of the area as shown in Figure-5. 


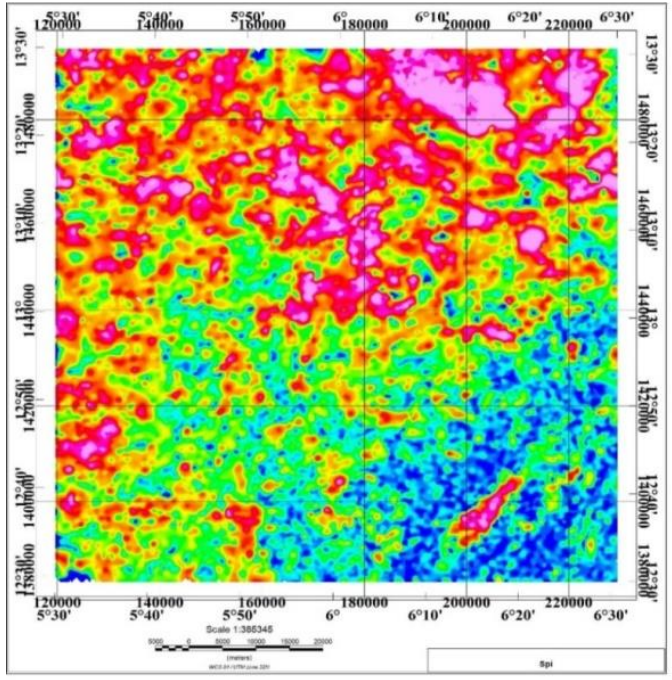

Fig-5: Source parameter map

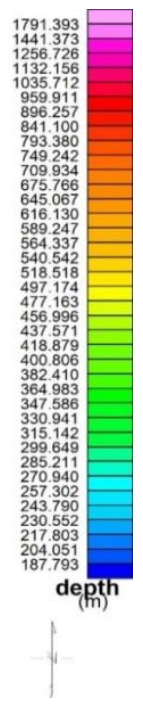

For Euler solutions, the best clustering solution was obtained by selecting a structural index of one (i.e. SI = 1). (Figure-6) Shows that the solution plotted clustered in the region where the geological structures are located shows depth range of $268.5 \mathrm{~m}$ to $2395.9 \mathrm{~m}$. The map shows deep magnetic bodies around Rabah and Isah.

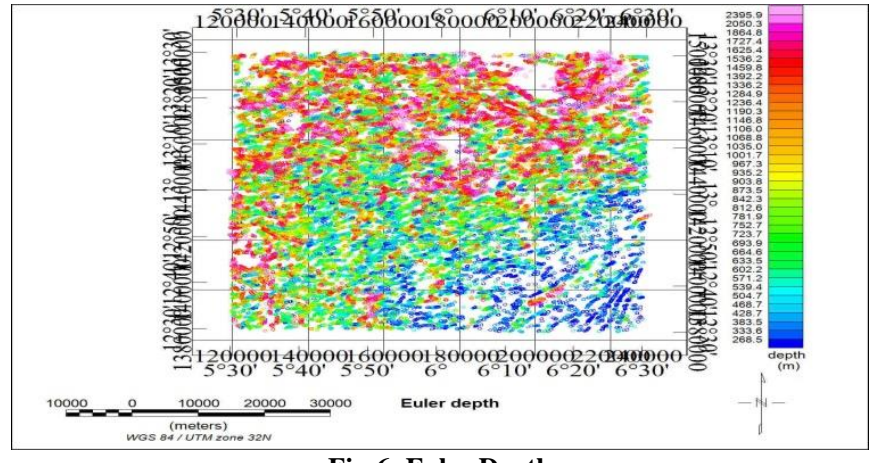

Fig-6: Euler Depth

In conclusion Quantitative interpretation carried out for Euler deconvolution methods and source parameter imaging, shows depth obtained by Euler depth analysis ranges from $268.5 \mathrm{~m}$ to $2395.9 \mathrm{~m}$. While source parameter imaging (SPI) depth values ranges from $187.793 \mathrm{~m}$ to $1791.393 \mathrm{~m}$. The thickness value for sediment in the study area for both source parameter and Euler deconvolution shows a maximum value of $1.791 \mathrm{~km}$ and $2.395 \mathrm{~km}$ respectively, which are observed to be the deepest areas in the study area and could be a possible potential zones to host hydrocarbon. Therefore, the quantitative analysis performed on the high resolution total magnetic intensity (TMI) data of the study area using Euler deconvolution and source parameter imaging technique conforms favorably to the results of other researchers such as Kamba and Ahmad [10] and Bonde et al., [12]. According to Wright et al., [4], the minimum thickness for the concealment of hydrocarbon is about $2.3 \mathrm{~km}$.

Based on the results obtained from this research it is recommended that more detailed geophysical and geological investigation should be carried out, as the area could be a potential source for finding hydrocarbon.

\section{REFERENCES}

1. Reford, M. S., \& Sumner, J. S. (1964). Aeromagnetics. Geophysics, 29(4), 482-516.

2. Sharma, O. P., \& Butler, T. L. (1987). Predictions of endwall losses and secondary flows in axial flow turbine cascades. Journal of turbomachinery, 109(2), 229-236.

3. Hamza, H., \& Graba, I. (2010) Challenges of exploration and utilization of hydrocarbons in the Sokoto Basin. Paper presented at International Conference on the Potentials of Prospecting for Hydrocarbons in the Sokoto Basin on 11th May, 2009 at Usmanu Danfodio University Sokoto, Nigeria.

4. Wright, J. B., Hastings, D. A., Jones, W. B., \& Williams, H. R. (1985) Geology and Mineral Resources of West Africa. George Allen and Unwin Ltd; UK. 107-108. 
5. Kogbe, C. A. (1981). Cretaceous and Tertiary of the Iullemmeden Basin of Nigeria (West Africa). Cretaceous Research, 2, 129-186.

6. Adeleye, D. R. (1979). A review of Maastritchian paleogeography of the southern Iullemmeden and Nupe Basins. Nigeria Journal of Mining and Geology, 10-14.

7. Obaje, N. G., Aduku, M., \& Yusuf, I. (2013). The Sokoto Basin of northwestern Nigeria: A preliminary assessment of the hydrocarbon prospectivity. Petroleum Technology Development Journal, 3(2), 66-80.

8. Kogbe, C. A. (1979). Geology of the South Eastern (Sokoto) Sector of the Iullemmeden Basin. Department of Geology, Ahmadu Bello University.

9. Obaje, N. G. (2009). Petroleum Resources. In Geology and Mineral Resources of Nigeria (pp. 155-181). Springer, Berlin, Heidelberg.

10. Kamba, A. H., \& Ahmed, S. K. (2017). Depth to Basement Determination Using Source Parameter Imaging (SPI) of Aeromagnetic Data: An Application to Lower Sokoto Basin, Northwest, Nigeria. International Journal of Modern Applied Physics, 7(1), 1-10.

11. Ofoha, C. C., Emujakporue, G., Ngwueke, M. I., \& Kiani, I. (2016). Determination of Magnetic Basement Depth over Parts of Sokoto Basin, within Northern Nigeria, Using Improved Source Parameter Imaging (ISPI) Technique. World Scientific News, 50, 266-277.

12. E E, U., \& J K, R. (2014). Spectral depth analysis of Sokoto Basin. IOSR Journal of Applied Physics, 6, 15-21.
13. Okwokwo, O. I., Adetona, A. A., Adewumi, T., \& Adeniran, S. O. (2018). Interpretation of high resolution aeromagnetic data to determine sedimentary thickness over part of Bida Basin, North Central Nigeria. Journal of Geology and Mining Research, 10(6), 72-80.

14. Sawuta, J. M., Ayanninuola, O. S., Udensi, E. E., \& Ogwola, P. (2019). Estimation Of Magnetic Depth To Source Using High Resolution Of Aeromagnetic Data Of Parts Of Upper Benue Trough, North Eastern Nigeria. Science World Journal, 14(1), 7-11.

15. Phillips, P. J., Wechsler, H., Huang, J., \& Rauss, P. J. (1998). The FERET database and evaluation procedure for face-recognition algorithms. Image and vision computing, 16(5), 295-306.

16. Thompson, D. T. (1982). EULDPH: A new technique for making computer-assisted depth estimates from magnetic data. Geophysics, 47(1), 31-37.

17. Reid, A. B., Allsop, J. M., Granser, H., Millett, A. T., \& Somerton, I. W. (1990). Magnetic interpretation in three dimensions using Euler deconvolution. Geophysics, 55(1), 80-91.

18. Nabighian, M. N. (1972). The analytic signal of two-dimensional magnetic bodies with polygonal cross-section: its properties and use for automated anomaly interpretation. Geophysics, 37(3), $507-$ 517.

19. Biswas, A., Parija, M. P., \& Kumar, S. (2017). Global nonlinear optimization for the interpretation of source parameters from total gradient of gravity and magnetic anomalies caused by thin dyke. Annals of geophysics, 60(2), 218. 